NBER WORKING PAPER SERIAS

THE COSTS OF WORKER DISPLACEMENT

Daniel S. Hamermesh

Working Paper No. 1495

NATIONAL BUREAU OF ECONOMIC RESEARCH

1050 Massachusetts Avenue

Cambridge, MA 02138

November 1984

Professor of Economics, Michigan State University, and Research Associate, National Bureau of Economics Research. Helpful comments on earlier versions of the is paper were received from David Card, Carl Davidson, Harry Holzer and participants at seminars at the National Bureau of Economic Research and a number of universities. This research was supported in part by a contract to the Institute for Research on Poverty of the University of wisconsin from the U.S. Department of Health and Human Services. The views expressed in this paper are those of the author and do not necessarily reflect the views of either DHHS or the Institute for Research on Poverty. The research reported here is part of the NBER's research programs in Labor Studies and International studies. Any opinions expressed are those of the author and not those of the National Bureau of Economic Research. 
NBER Working Paper 非 1495

November 1984

The Costs of Worker Displacement

ABSTRACT

This study defines the nature of worker displacement and develops a mechanism for inferring the amount of losses caused by displacement in a way that is tied to economic theory. Data from the Panel study of Income Dynamics are first used to identify the characteristics of displaced workers. After a demonstration that usual methods of evaluating workers' losses cannot prouide correct measures of the cost to society, a game-theoretic model determining the amount of firm-specific investment in workers is developed. As workers' and firms' horizons decrease, such investment will be reduced; this will be exhibited in a flattening of the wage-tenure profile as the date of displacement approaches. Examination of the profile thus prouides a test whether firms and workers have good information about impending displacement.

Using the PSID data for workers displaced between 1977 and 1981 , the study shows there is no significant flattening of the wage-tenure profile in the entire sample. (However, some flattening does occur among unionized workers, and also among workers who are laid-off permanently from a plant that remains open.) This suggests that workers are surprised by displacement, for they continue inuesting in firm-specific human capital up to the time of displacement. The present value of the worker's share of the lost returns on this investment is around $\$ 7000$ (1980 dollars) under intermediate assumptions about the real rate of discount, depreciation on such investment and the effect of tenure on the rate of voluntary separation.

Danie1 S. Hamermesh Department of Economics Michigan State University East Lansing, MI 48824 (517) 355-7349 
1. Introduction

Perhaps the liveliest recent discussion of labor-market policy has been about declining industries and the workers attached to them. Calls for an inchoate "industrial policy;" proposals to aid "displaced workers;" and attempts to prevent future losses, are all responses to this perceived problem.' In this study I consider the meaning of the notion "displaced worker" and present a partial evaluation of the magnitude and burden of the costs produced by displacement. In essence the study thus examines the costs of adjustment to shifts in production, transaction costs that are presumabiy outwe ighed by the long-run improvement in the allocation of labor.

The term "displaced worker" is not well specified. ${ }^{2}$ Therefore, I use a national sample of workers to identify the characteristics of those who might be classified as displaced. Most important, the study devises a method for specifying and measuring the cost to society of these workers' job losses. The output of this approach is an answer to the question whether workers experience a loss in human capital upon losing their jobs, or whether the loss is solely a reduction in the rents sto characteristics such as sex, race, union status, ete.) that accrued on their previous jobs. As such, it provides a way of evaluating the costs of worker displacement that is more closely grounded in economic theory than is the existing literature which is summarized in Baldwin, 1984). This method can provide the basis for schemes that might be offered to compensate for losses attendant on worker displacement.

11. Who Are Displaced Workers?

In order of increasing breadth, three definitions of a "displaced worker" can be applied to existing data. The narrowest includes only those workers 
whose job losses resulted from competition from imports. Its difficulty is its inability to identify which job losers are unemployed because of import competition. ${ }^{3}$ Indeed, empirically it is difficult to distinguish these job losses from those that result from high casts induced by wage rates in excess of those paid to otherwise identical workers.

A less narrow definition includes all workers whose jobs disappeared because their employer closed the plant or business. The difficulty with this definition is that it distinguishes artificially among workers depending on whether the employer closed or merely curtailed operations. Thus a third, and still wider definition, adds to these workers others who lost their jobs through layoffs that were not part of the closing of an entire plant. In this section I use these last two definitions to examine the characteristics of workers who might be classified as displaced. One should note that both definitions relate to the nature of workers' separation from their previous jobs; neither depends upon their current labor-force status.

While other studies have counted workers who might be categorized as "displaced," none has been able to distinguish between the second and third definitions. 4 use the Panel study of Income Oynamics to identify workers who left their jobs ither because they were laid off or because the employer's business closed. 5 I thus distinguish between workers identified as "laid-off" and those called "displaced," even though both can be classified as displaced according to the third definition above. Among national samples the PSID is unique in making this distinction.

Table 1 presents estimates of the extent of displacement, and of the characteristics of displaced workers, based on the PSID for the years 1969 through 1981. 6 The Table is based only on heads of households (since the data are available only for them); some involuntary separations are missing, and 
Table 1

CHARACTERISTICS OF DISPLACED AND LAID-OFF WORKERS, AND ALL HOUSEHOLD HEADS, PSID, 1969-81

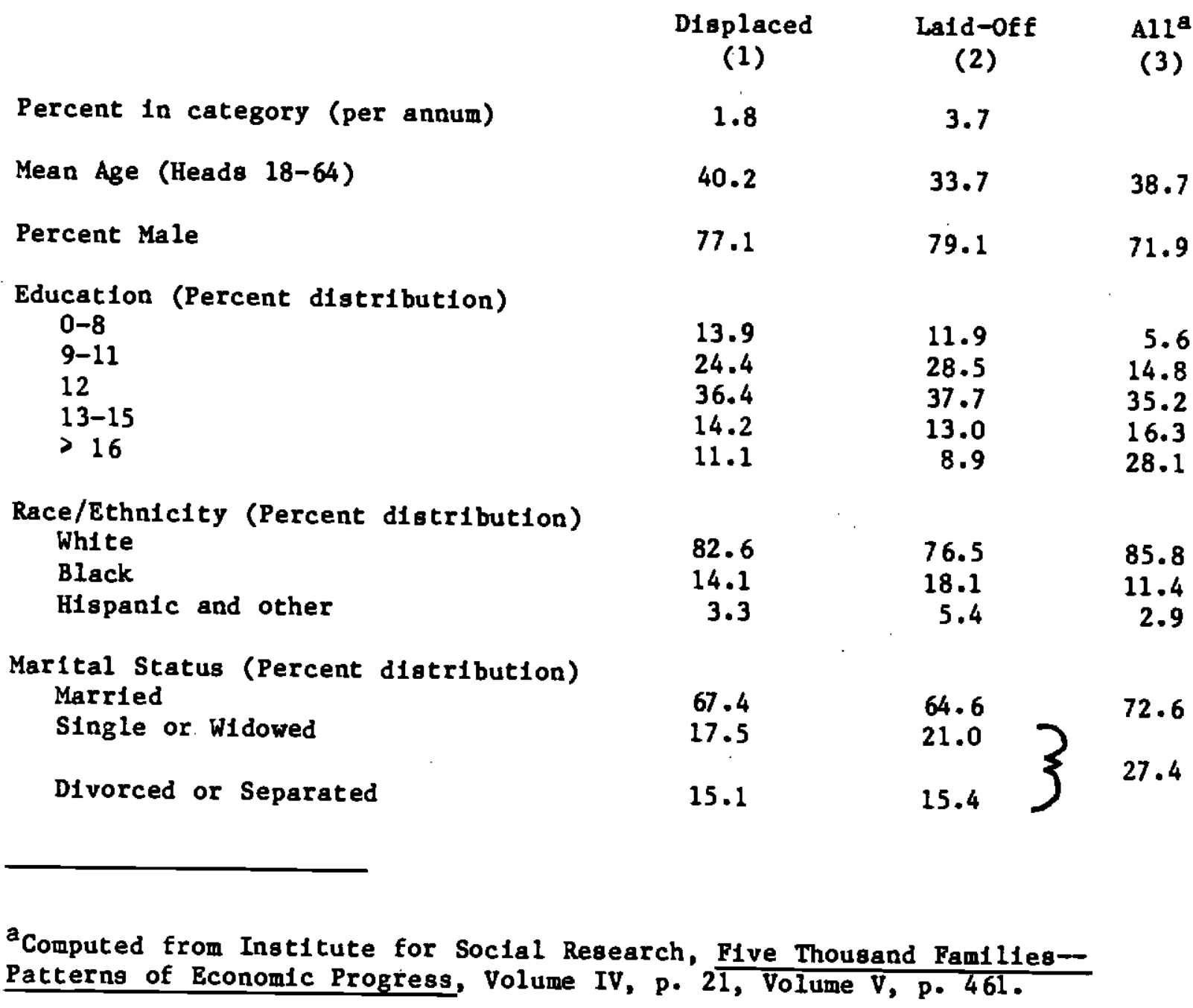


the data may be overstating or understating national average displacement rates, depending on whether household heads are more or less likely to be subject to displacement. As the Table shows, the rate of "displacement" is roughly half that of the layoff rate. Despite this difference, though, a surprisingly large fraction of workers lose their jobs each year because the entire place of business closes.

Only two aspects of the demographic characteristics of job losers are surprising. One would expect, given the common practice sin both union and nonunion establishments) of layoffs by inverse seniority, that permanently laid-off workers are fairly young. This is borne out by a comparison to the average age of all household heads in the PSID sample. However, displaced household heads are not substantially older than the typical head in the PSID. The incidence of displacement does not fall disproportionately on the older worker (though the burden of any private loss may). The other unexpected characteristic is the fairly low percentage of displaced workers who are married. Perhaps the unobserved characteristics of individuals who are displaced from jobs overlap those characteristics that led them to fail to find satisfactory matches in the marriage market.

Both laid-off and displaced workers have lower educational at tainment than does the typical household head, and both groups are less likely to contain non-Hispanic whites than the typical household. There is little difference between laid-off and displaced workers in educational attainment. However, it is noteworthy that the composition of this group of workers who experience plant closings is much more representative of the racial/ethnic mix of household heads than is that of laid-off workers. Using the broader definition of displacement makes the problem more closely coincident with the problems of minorities in the labor market. That both laid-off and displaced 
groups consist disproportionately of men is unsurprising given the lower labor-force participation rates of female heads of households.

\section{II. The Nature of the Losses}

The large literature on displacement in the labor market stems mainly from an interest in the effects of foreign competition. This literature has evaluated the losses incurred by displaced workers using two approaches coften together.) The first considers the value of the time the displaced worker spends unemployed (Bale, 1976; Neumann, 1978); the second compares workers' wages or earnings on the job that was lost to those on the job eventually obtained (Jacobson, 1978; Jenkins-Montmarquette, 1979; Kiefer-Neumann, 1979; Sandell-Shapiro, 1983; Glenday-Jenkins, 1984). Only if: 1) Workers realize that the characteristics that produced rents on the previous job have no effect on the wage-offer distribution they must search over; 2 ) There is no unemployment insurance; and 3) Earnings obtained on the previous job are adjusted appropriately, can one obtain a correct estimate of the cost to society.

To see the first point, assume that the wage on the previous job was:

(1) $w_{b}=G\left(x, z_{b}\right)$,

where $b$ denotes the previous job, $X$ is a vector of characteristics of the worker that yield the same return on average on the previous job and in the market generally, and $z$ is a vector of characteristics that cannot ex post be expected to yield equal returns on subsequent jobs. Thus, for example, the union status of the previous job (see wachter, 1983); returns to racial or ethnic favoritism, or accumulated firm-specific human capital are included in Z. Let the worker's reservation wage after displacement be characterized as: 
(2) $W^{r}=H\left(\mu *, 0^{*}\right)$,

where the starred variables in $H($.$) are the mean and standard deviation of the$ density function of wages that the worker perceives at the time of di splacement.

Assume the displaced worker searches a density function of wages that is in fact described by $f(W), 0<W<-$. Let $F\left(W_{*}\right)$ be the distribution function of $f$ from 0 to $W^{*}$. Assuming for simplicity that the worker samples one offer each time period, the average duration of unemployment, $D, w i l l$ be $1 /\left[1-F\left(w^{r}\right)\right]$, and the wage rate on the worker's new job will be:

(3) $w_{a}=\int_{W^{r}}^{\infty} w f(W) d W /\left[1-F\left(w^{r}\right)\right]$.

So long as $w^{r}$ is affected by $Z_{b}$, i.e., so long as the mean and variance of the ex (ante) perceived distribution of offered wages are affected by characteristics specific to the previous job, the duration of unemployment and the subsequent wage will be affected by those characteristics. The duration of unemployment will be longer and the subsequent wage will be higher than otherwise. 8 These biases arise because workers leave their jobs with inflated expectations of how the market will reward them for some of the characteristics that raised their wages there, not because of problems in specifying the error structure of equations describing duration or $w^{r}$. Simply relating wages before displacement to those obtained on the next job, as is proposed in most of the studies cited above, will thus produce erroneous estimates of the social cost of displacement. As I have shown, there is an implicit simultaneity between wages on the two jobs that works through the relation between the reservation wage and the components of $z_{b}$. Even though those components may not be productive outside the original job, they will affect the entire function describing wages on subsequent jobs. The 
second point follows from the same logic as the first: The presence of unemployment insurance will induce workers to search longer, also producing longer unemployment and a smaller drop in wages than would otherwise be the case.

Ignoring these two problems, one must (see Sandell-Shapiro, 1983) adjust wages (not wage functions) on the previous job for differences in the components of $Z$ between jobs. The difficulty with even this partial solution to the errors implicit in before-after wage comparisons is that not all of what is lost when the values of the components of 2 change represents a loss to society. For example, rents may have accrued because some factor that protected the worker from competition may be lost if a new job is not similarly protected. If the job from which the worker is displaced is unionized, but the job subsequently obtained is not, the worker suffers a loss in wages, ceteris paribus. However, the loss should not affect the ability of employers in the union sector to fill jobs in the future?

Also included in the loss may be a reduction in human capital. Workers and firms invest in human capital expecting some horizon over which the returns will be reaped. Impending displacement may represent a shortening of the horizon and perhaps a capital loss to the worker andor the firm. Here the distinction between general and specific training is crucial. General training is included in $X_{i}$ by definition it is as applicable in any subsequent job as in the job that disappeared. Firm-specific human capital, however, is included in $Z_{b}$ and is lost when the worker leaves the firm. This investment may have been made with the expectation of a longer payout period than in fact occurred. Both the firm and the worker may suffer a capital loss because of the separation, with the size of each party's loss dependent upon the length of the payout period that was expected, the amount invested, and the sharing 
of investment costs. 10

These considerations suggest that the social costs in the labor market include at least the lost firm-specific human capital, measured using information uncontaminated by the biases induced by the effect of $z_{b}$ on subsequent wages. Firm-specific human capital is the only component in $z_{b}$ that clearly has no productivity on any subsequent job and that represents an investment on which the return may be below-market. Displaced workers may reap below-market returns on their investment in occupation- or industry-specific skills; but, unless the entire occupation or industry disappears at once, the magnitude of this loss is also affected by the worker's search behavior in the face of a (possibly changing) distribution of returns to these skills. Similarly, there is a social loss that is positively related to the excess of the displaced workers' market wages over their reservation wages, and to the duration of time they spend between jobs. Both components of the loss that occurs during the time the workers are unemployed are affected by their search behavior, and thus possibly by characteristics of their previous jobs. For these reasons the remainder of this study examines lost firm-specific investment, recognizing that society may also lose both the worker's labor services during the time between jobs and part of a stream of expected returns on investment in skills specific to an occupation or industry. 11

IV. Inferring the Effects of Impending Displacenent

Measuring lost firm-specific human capital is not an easy task, insofar as the stock must be inferred from wages, and the costs of investment in firm-specific human capital are shared by workers and firms. Nonetheless, one can use data on wage-tenure profiles along with some consideration about the 
efficient split of investment costs between workers and firms to answer the questions: 1) Is there any loss? That is, are investments being made that have a payout period that extends beyond the date of displacement? and 2) If so, which party, the worker or the firm, bears the costs of these ex post poor investments?

Consider the following technology for producing firm-specific training:

$$
B=B(t),
$$

where $t$ is the fraction of the initial period of employment that is spent in training. SAll firm-specific training is assumed to take place during this first period.) $B$ is the amount that the training adds to the worker's productivity each period; it is assumed constant over the entire life of the investment. I assume that production of specific training is characterized by diminishing returns, i.e., $B^{\prime}>0, B^{\prime \prime}<0$, and that $B(0)=0$. The costs of producing the training are also a function of $t$, with $c(t)$ described by $c^{\prime}, c^{\prime \prime}>0$, and $C(0)=0$. There is little evidence either way on the assumptions describing the shapes of $B$ and $C ;$ I have merely made standard assumptions about technologies. 12 In making them 1 also ignore for simplicity any costs of training other than the value of trainees' time.

The worker and the firm are assumed to have identical discount rates and have utility functions $U, U^{\prime}>0$, U'<0, defined over the benefits and costs of firm-specific training. ${ }^{13}$ Let $T_{i}$ be each party's horizon, the length of time it expects to reap returns on the investment in specific training, where $i$ refers to the firm (F) or the worker (W). This assumption implies point expectations about the duration of the job. It too is simplifying; but the results carry through with the more realistic assumption that both workers and firms maintain subjective probability distributions about the job's duration. 
The worker bears some fraction $s$ of the cost of the investment and reaps that same fraction of the expected returns. The worker's expected utility stream is thus defined as:

$$
Z_{W}=U(s B(t)) \sum_{k=1}^{T_{W}} D^{k}+U(-s C(t))
$$

where $D$ is the discounting factor $1 /[1+r], Z_{F}$ is identical to $Z_{W}$ except $1-s$ replaces $s$, and $T_{F}$ replaces $T_{W}$.

Because this is a shared investment, in which each side has monopoly power, the outcomes, t*, the optimal fraction of the initial period spent investing, and s*, the optimal fraction of the benefits and costs accruing to the worker, are subject to bargaining between the firm and the worker. The Nash equilibrium solution to this bargaining problem is the pair \{t*, s*\} that maximizes:

$$
\text { (6) } Z=Z_{F} Z \text {. }
$$

Assuming $T_{F}=T_{W}$, the assumption of identical discount rates and utility functions produces the standard Nash result that $5 *=.5$, and some $t *>0$ if $\left.z_{i}(t *\rangle 0 \mid T_{i}\right)>Z_{i}\left(t *=0 / T_{i}\right)$.

The burden of displacement is based in the parties' expectations about the nature of the shortened horizon over which the shared returns to the investment in firm-specific training will be reaped. Thus the nature of the information available to both sides about the continued existence of the job in which the investment has been made determines $t *$ and $5 *$. I examine cases in which the information available to each party is identical (symmetric), and in which the firm has better information about the job's impending demise (asymmetric). Asymmetry in the opposite direction, with the worker better able to foresee the job's disappearance, seems unlikely given the firm's control 
over decisions about operating its plant.

CASE I.A. Symmetric Lack of Information

In this case neither party is aware that the job will disappear until the day the firm discovers that its profit-maximizing conditions dictate that the worker be laid-off permanently (or the plant closed). Thus at all times up to the date of separation the horizon seen by workers and the firm is unchanged at $T_{F}=T_{W}$, both greater than the ex post payout period of the returns to the investment. Since in this case the information is identical to what it is in the absence of any information about the job's disappearance, the outcome of the bargaining problem that determines $t *$ and $s *$ is unchanged. Both parties will experience a capital loss when the displacement occurs.

CASE I.B. Symmetric Information About Impending Displacement

Assume in this case that the worker and the firm realize that, because of an exogenous drop in product demand, the worker's expected tenure in the firm has dropped to $T^{\prime}{ }_{W}\left\langle T_{W}\right.$. Because information is symetric, $T^{\prime}{ }_{F}=T^{\prime} W^{\text {. This change }}$ reduces both parties' perceived utility from investing in specific training. If training is still profitable at some $t *>0$, it will be undertaken. And, since the 2 ; are still equal (though reduced), $5 *$ remains at .5 . Given the assumptions about the shapes of $B$ and $C$, though, $t *^{\prime}\langle t *$ : With a shorter horizon over which to reap the returns to firm-specific training, a smaller investment in such training will be made. The size of the profit over which the parties bargain will be smaller. For some $T^{*}$ the investment will no longer be profitable and t* will be zero.

Case II. Asymmetric Information 
Asymmetric information about an impending job loss presumably means that both the worker and the employer realize the horizon has shortened, but the firm acquires this information first. However, the general nature of the problem can be analyzed just as well if we assume that the worker has no knowledge that the layoff is imminent, while the firm knows the horizon has shortened. Thus:

$$
T_{W}^{\prime}=T_{W}>T_{F}^{\prime}>0
$$

This means that the stream of returns seen by the firm is lower for every $t$ at $s^{*}=.5$ than that perceived (incorrectly) by the worker.

Because information is asymetric, the Nash solution no longer applies; and unfortunately the game-theory 1 iterature has not produced an explicit solution to the noncooperative game implicit in the assumption of asymetry. Let us therefore merely consider two possible situations under this assumption. If $T_{F}$ is sufficiently short, the firm will realize that it cannot make any profit if s/1. The solution is no longer bargained: The amount invested is determined solely by the worker maximizing $Z_{w}$ with $5 *=1$, with $t *$ smaller than before due to the shape of the worker's utility function. If $T_{F}$ is not this short, the parties are engaged in a noncooperative bargaining situation. While nothing can be inferred with certainty about the outcome, one might assume that continuity applies. If so, as $T_{F}$ increases just beyond the point where the $\mathrm{firm}$ is indifferent about taking part in bargaining over $s$ and $t, 5^{*}$ will be close to one. That being the case, t* will also be lower than it was before the firm acquired information that led it to revise its horizon.

One might ask why workers do not recognize that an increase in s* signals that $T_{F}$ has decreased and reduce $T_{W}$ too. This question is equivalent to 
viewing the bargaining process over $s$ and $t$ as a supergame, in which each party learns from the outcome of a particular solution $\left(t *, s_{*}\right)$ something about the other party's horizon and modifies its own behavior accordingly on the next round. Indeed, if there were sufficient rounds in such a supergame and the firm knew with certainty the date of closing, there would be no loss from displacement: Workers and firms would repeatedly modify the amount and sharing of investment based on the firm's horizon, as revealed by the outcomes of the previous stage. Investment would occur along a path such that the value of firm-specific human capital was zero at the date of displacement. What the empirical work in this study does is test whether in fact information is sufficient and the parties are clever enough bargainers to avoid investments that will not pay off.

The likely outcomes on $5 *$ and $t *$, both the Nash solutions when $T_{F}=T_{W}$ and the results when information is asymetric, are shown in Figure 1 as functions of $T_{F}$ and $T_{W}$. The greater the divergence between the parties horizons, the more the split in the benefits and costs of the investment differs from .5 .14 The shorter the horizons become, the smaller the investment will be.

This discussion allows us to use changing wage-tenure profiles to infer the information available to displaced workers and their employers. 1) If the profile does not change as workers near displacement, ither Case I.A. is correct, or Case II is valid, but workers' horizons have decreased somewhat. 2) If the profile becomes flatter as the date of displacement draws nearer, either Case I.B. is correct, and firms and workers have the same, fairly good information about the impending displacement; or the asymmetric case II is correct, but the worker's information is sufficient to reduce the total amount invested by more than enough to offset the worker's increased share of the costs of training. ${ }^{15}$ 3) If the profile becomes steeper as the date of 


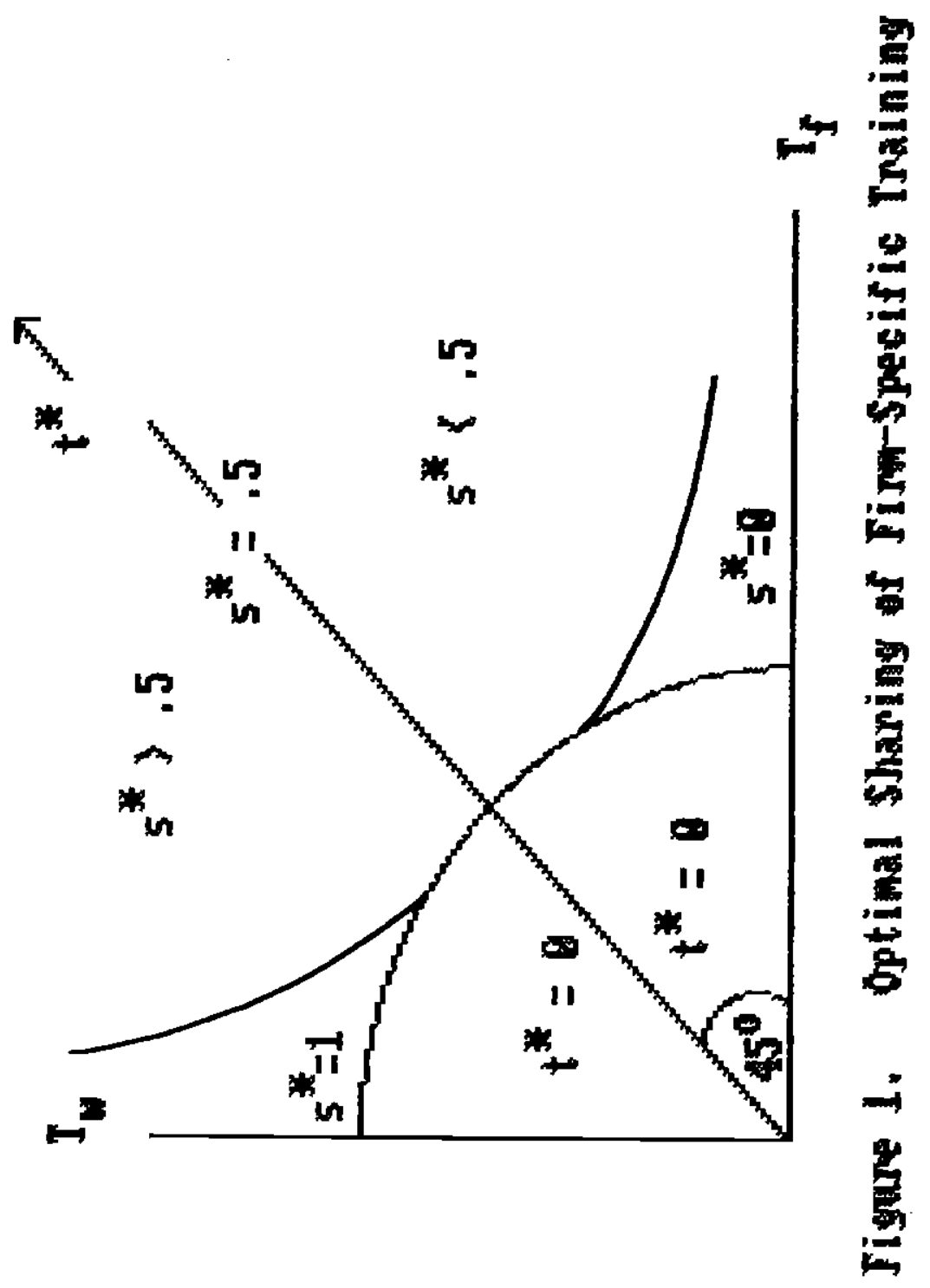


displacement approaches, we may infer that the asymetric case is correct and that the total amount invested $(t *)$ does not decrease greatly. (If it did, the wage-tenure profile would be unchanged or flattened. ${ }^{16}$,

workers in firms in which the risk of involuntary separation is larger, other things equal, receive a compensating wage differential (Abowd-Ashenfelter, 1981; Topel, 1984) for the risk of unemployment, perhaps one sufficient to compensate also for the potential loss of firm-specific human capital. Both displaced workers and others in the same firms will receive this extra pay. What is considered here is whether there are any losses of such capital, or whether the differential need only compensate for the time the displaced workers expects to spend unemployed.

V. Measurement and Estimation

In this and the next section I examine the determinants of wages of both displaced and laid-off workers. The basic equations to be estimated are of the form:

(7) In $w=8 z+\gamma z^{\prime}$,

where $w$ is the wage on the worker's main job, 2 is a vector of control variables, and $z^{\prime}$ is a vector containing measures of total experience and tenure. The data used are from the Panel study of Income Dynamics.

The PSID has the virtue of providing a long, continuous panel, but it has one severe drawback for our purpose: Tenure with the employer, a measure of the time available for investment in firm-specific training, is reported only in the interviews of 1976 and 1977.17 since the main purpose is to observe the wage-tenure relationship among workers who are later displaced, this lack greatly restricts the number of observations from the PSID that can be used. 
CBecause no information on the tenure of people who report themselves displaced in 1976 or earlier is available, only people displaced between 1977 through 1981 have the required information.) The paucity of data on tenure with the employer combines with workers' mability to limit the sample still further: Many of the workers involuntarily separated in, e.g., 1981 had changed jobs several times since 1977, when their tenure was last reported. 18 Equation ( 7 ) is estimated using observations for years T-1, T-2, T-3 and $T-4$, where, as before, $T$ is the date of involuntary separation. ${ }^{19}$ starting with 1421 household heads who left their jobs because of a permanent layoff or a plant closing in 1977-1981, the exclusions reduce the sample sizes in the estimates of (7) in years $T-i, i=1, \ldots, 4$, to $362,305,246$ and 200 observations respectively. Of these people, 36 percent of those included in the samples for T-2, T-3 and T-4 were displaced workers, while 33 percent of the sample for $T-1$ were.

The variables included in 2 are standard in equations like (7). Among them are: Years of formal education, or a vector a dummy variables for completion of college, some college, or completion of high school; whether the worker is a union member, white, married, or male; whether the worker resides in the South or in an SMSA in which the largest city has a population above 500,000 ; the worker's occupation in the job that disappeared cprofessional or manager, (raft, or operative or laborer); and the industry of that job (manufacturing, wholesale and retail trade, or finance and services). The means of these variables in the four samples suggest these involuntarily separated workers are not typical of the U.S. Iabor force: There are fewer whites, more Southerners and more manufacturing workers. These differences are consistent with the PSID's oversampling of low-income households and with the greater propensity of manufacturing employers to lay off workers. 
The variables included in $2^{\prime}$ are tenure with the employer, $T N$, and years of actual full-time labor-market experience since age 18, $X$. A quadratic term in experience is also included in the equations, as is a quadratic term in tenure in some of the estimates. The average tenure prior to involuntary separation is only five years. Nonetheless, between 33 and 37 percent of the workers in the four samples had more than five years' tenure with their employer, and between 17 and 20 percent had at least ten years of tenure. The average total experience in the samples implies a mean age in the middle thirties, roughly what is implied for all laid-off and displaced workers in Table 1.

UI. Estimates of Wage Profiles Among Displaced and Laid-off Workers

The estimates of $\beta$ in (7) for those variables not in $Z^{\prime}$ are shown in Table A.1. The results are quite standard among estimates of wage equations using micro data and merit little comment here. Suffice it to note that their very routineness suggests that, along most dimensions that produce wage differentials, the particular samples selected from the PSID are not unusual.

Table 2 presents the estimates of the parameters on the experience and tenure variables from (7), including only a linear term in tenure. The wage-experience profiles have shapes that have generally been found in research in this area (e.g., Mincer-Jovanovic, 1981). However, the results in Table 3, which include a quadratic term in tenure, show only slight evidence of the usual concauity in the wage-tenure profile. This may result from the peculiar nature of the sample, from the use of tenure with the employer instead of the less appropriate tenure in the job that has been used in many studies, or from the relatively small samples that the focus on involuntary separations produces. 
The major issue of interest in this study is the pattern of effects of tenure with the firm. As a comparison of the coefficients in Table 2 on this variable makes clear, there may be some flattening of the wage-tenure profile, but it is not very pronounced. The profile is still far from flat even in the year immediately preceding displacement. 20 It may of course be that the profiles for all four years are much flatter than those for years $t-5$ and earlier, and flatter than those for workers who are not separated involuntarily. However, the slopes in Table 2 are remarkably close to those produced by Altonji-Shakotko (1984) using similarly specified equations covering employed white males in the PSID.

Consider how the wage-tenure profiles vary with the worker's union status. Trade-union wage-setting differs from that in nonunion plants in the effects of experience on wage rates (see Johnson-Youmans, 1971) and in how workers process information about the workplace (see Freeman, 1980). It may be that unionized workers, merely because the union provides a means of gathering information about the employer's plans, avoid investments in specific human capital that will not pay off, an avoidance that would be reflected in wage-tenure profiles that flatten out as displacement approaches.

The results of estimating (7) including interaction terms of experience and tenure with union membership are shown in Table 4, While the vector of interaction terms is not jointiy significantly different from zero, the results are nonetheless suggestive. The use of a quadratic in $x$ makes it difficult to infer the effect of unionism on changes in the wage-experience profile simply by inspection, and I defer the discussion of that issue. However, inspection of the interaction terms with tenure suggests a striking pattern: The wage-tenure profiles for union workers are much steeper in the third and fourth years before displacement than they are in the first and 
Table 2

Tenure and Experience Varlables, Wage Regressionsa/

\begin{tabular}{|c|c|c|c|c|}
\hline & 1 & $\begin{array}{c}\text { Years Before } \\
2\end{array}$ & $\begin{array}{c}\text { splacement } \\
3\end{array}$ & 4 \\
\hline $\mathrm{X}$ & $\begin{array}{l}.0119 \\
(2.36)\end{array}$ & $\begin{array}{l}.0209 \\
(3.55)\end{array}$ & $(2.0181$ & $\begin{array}{l}.0167 \\
(2.75)\end{array}$ \\
\hline$x^{2}$ & $\begin{array}{l}-.00026 \\
(-2.48)\end{array}$ & $(-3.09)$ & $\begin{array}{l}-.00045 \\
(-2.83)\end{array}$ & $\begin{array}{l}-.00042 \\
(-3.38)\end{array}$ \\
\hline $\mathrm{TN}$ & $\begin{array}{l}.00896 \\
(2.40)\end{array}$ & $\begin{array}{l}.00619 \\
(1.59)\end{array}$ & $\begin{array}{l}.01049 \\
(2.42)\end{array}$ & $\begin{array}{l}.01070 \\
(2.62)\end{array}$ \\
\hline$\overline{\mathrm{R}}^{2}$ & .54 & .50 & .45 & .59 \\
\hline
\end{tabular}

at-statistics in parentheses here and in Tables 3-5. The estimates are from equations in which the full vector of variables $z$ is included. 
Table 3

Tenure and Experlence Varlables, Expanded Wage Regressions

\begin{tabular}{|c|c|c|c|c|}
\hline & \multicolumn{4}{|c|}{ Years Before Displacement } \\
\hline $\mathrm{x}$ & $\begin{array}{l}.0107 \\
(2.09)\end{array}$ & $\begin{array}{l}.0212 \\
(3.49)\end{array}$ & $(2.71)$ & $(2.0164$ \\
\hline$x^{2}$ & $\begin{array}{l}-.00024 \\
(-2.24)\end{array}$ & $\begin{array}{l}-.00038 \\
(-3.05)\end{array}$ & $\begin{array}{l}-.00048 \\
(-2.93)\end{array}$ & $\begin{array}{l}-.00042 \\
(-3.29)\end{array}$ \\
\hline TN & $\begin{array}{l}.01748 \\
(1.99)\end{array}$ & $\begin{array}{l}.00427 \\
(.42)\end{array}$ & $\begin{array}{l}.00235 \\
(.21)\end{array}$ & $\begin{array}{l}.01389 \\
(1.25)\end{array}$ \\
\hline $\mathrm{TN}^{2}$ & $\begin{array}{l}-.00037 \\
(-1.07)\end{array}$ & $\begin{array}{l}.00008 \\
(.20)\end{array}$ & $\begin{array}{l}.00038 \\
(.81)\end{array}$ & $\begin{array}{l}-.00014 \\
(-.31)\end{array}$ \\
\hline$\overline{\mathrm{R}}^{2}$ & .54 & .50 & .45 & .59 \\
\hline
\end{tabular}


Table 4

Tenure and Experience Variables, Including Interactions with Union Status

\begin{tabular}{|c|c|c|c|c|}
\hline & 1 & $\begin{array}{l}\text { Years Before } \\
\quad 2\end{array}$ & $\begin{array}{c}\text { 3placement } \\
3\end{array}$ & 4 \\
\hline$x$ & $(1.0096$ & $(2.70)$ & $\begin{array}{l}.0186 \\
(2.38)\end{array}$ & $(2.0144$ \\
\hline$x^{2}$ & $\begin{array}{l}-.00024 \\
(-2.08)\end{array}$ & $\begin{array}{l}-.00033 \\
(-2.55)\end{array}$ & $\begin{array}{l}-.00046 \\
(-2.61)\end{array}$ & $\begin{array}{l}-.00037 \\
(-2.72)\end{array}$ \\
\hline $\mathrm{X} \cdot \mathrm{UN}$ & $\begin{array}{l}.0040 \\
(.26)\end{array}$ & $\begin{array}{l}.0070 \\
(.02)\end{array}$ & $\begin{array}{l}-.0002 \\
(-.01)\end{array}$ & $\begin{array}{l}.0173 \\
(1.08)\end{array}$ \\
\hline$x^{2}$, UN & $\begin{array}{l}.00008 \\
(.21)\end{array}$ & $\begin{array}{l}.00004 \\
(.11)\end{array}$ & $\begin{array}{l}.00003 \\
(.08)\end{array}$ & $\begin{array}{c}-.00047 \\
(-1.12)\end{array}$ \\
\hline TN & $(1.81)^{.00873}$ & $(1.00821$ & $\begin{array}{l}.00223 \\
(.35)\end{array}$ & $(1.00916$ \\
\hline $\mathrm{TN}$ • UN & $\begin{array}{l}-.00304 \\
(-.40)\end{array}$ & $\begin{array}{l}-.00822 \\
(-1.04)\end{array}$ & $\begin{array}{l}.01322 \\
(1.49)\end{array}$ & $\begin{array}{l}.00416 \\
(.47)\end{array}$ \\
\hline
\end{tabular}


second years: Among union workers the slopes are .015 and .013 in years T-3 and $T-4$, and .006 and 0 in years $T-1$ and $T-2$. Among nonunion workers there is essentially no change in the steepness of the wage-tenure profile as displacement nears. This difference is consistent with the role of unions in providing information that protects workers from management discretion, in this case, information about impending involuntary separation.

Another possible difference in behavior may arise in those plants that experience closings. In such cases the employer may make more of an effort to hide information than in cases when an isolated worker, or group of workers, is to be laid off. To examine this possibility equations ( 7 ) were reestimated including interaction terms of the tenure and experience variables with the reason for involuntary separation. The results are shown in Table 5. The vector of interaction terms is jointly significant in the equations for year T-4, though not in the other equations. Most interesting, the implied slopes of the wage-tenure profiles decline steadily from .0213 to .0054 as the date of layoff approaches. Apparently, workers facing layoff obtain enough information about it to reduce their firm-specific investment. This is not true among the one-third of the sample who lose their jobs because of plant closings: The coefficients on TN alone in Table 5 show that the slope of the wage-tenure profile increases steadily as the date of closing nears. 21

The constancy of the slope of the wage-tenure profile with impending displacement suggests either that there is an asymetry in the information available to workers and their employers about the timing of the displacement, or that neither party can plan well for it. Since it is unlikely that workers have more information than their employers, the invariance of the wage-tenure profiles with time remaining until separation shows that there is a high degree of ignorance on the part of the workers. If workers' knowledge of the 
Table 5

Tenure and Experience Variables, Including Interactions wth Cause of Dioplacement

\begin{tabular}{|c|c|c|c|c|}
\hline & & Years Befor & placement & \\
\hline & 1 & 2 & 3 & 4 \\
\hline $\mathrm{x}$ & $(1.74)$ & $\begin{array}{c}.0264 \\
(3.02)\end{array}$ & $\begin{array}{c}.0159 \\
(1.48)\end{array}$ & $(2.019)$ \\
\hline$x^{2}$ & $\begin{array}{l}-.00032 \\
(-2.24)\end{array}$ & $\begin{array}{l}-.00048 \\
(-3.05)\end{array}$ & $\begin{array}{l}-.00043 \\
(-1.94)\end{array}$ & $\begin{array}{l}-.00048 \\
(-2.83)\end{array}$ \\
\hline$X \cdot$ LAIDOFF & $\begin{array}{l}-.0045 \\
(-.43)\end{array}$ & $\begin{array}{c}-.0143 \\
(-1.14)\end{array}$ & $\begin{array}{l}-.0014 \\
(-.10)\end{array}$ & $\begin{array}{l}-.00169 \\
(-.13)\end{array}$ \\
\hline $\mathrm{X}^{2} \cdot$ LAIDOFF & $\begin{array}{l}.00015 \\
(.68)\end{array}$ & $\begin{array}{l}.00031 \\
(1.10)\end{array}$ & $\begin{array}{l}.00006 \\
(.17)\end{array}$ & $\begin{array}{l}-.00006 \\
(-.22)\end{array}$ \\
\hline TN & $\begin{array}{l}.01019 \\
(2.07)\end{array}$ & $\begin{array}{l}.00406 \\
(.83)\end{array}$ & $\begin{array}{l}.00658 \\
(1.20)\end{array}$ & $\begin{array}{l}.00124 \\
(.24)\end{array}$ \\
\hline TN • LAIDOFF & $\begin{array}{l}-.00473 \\
(-.63)\end{array}$ & $\begin{array}{l}.00343 \\
(.43)\end{array}$ & $\begin{array}{l}.00851 \\
(.96)\end{array}$ & $(2.41)$ \\
\hline
\end{tabular}


impending displacenent were less than employers', but still substantial, total firm-specific investment would drop so much that workers' costs of an increased share of the investment would fall. 22

Because the quadratic terms in experience make it difficult to infer any changes in the pattern of investment in general training as the date of displacement approaches, for each year before displacement Table 6 shows the average wage in the samples as a function of experience, evaluated at the means of the other variables. The clearest result is the lack of change in the wage-experience profile as displacement approaches. Even among union workers, whose wage-tenure profiles indicated they had fairly good information about the displacement, the wage-experience profile changes little. Oniy when the profiles are calculated for laid-off workers separately is there a noticeable steepening, while among workers affected by plant closings the profile flattens out.

At first consideration the results for the subgroups, and for the entire sample, are surprising. If workers were fully rational, had perfect information about the impending displacement, and did not face any liquidity constraints, they would invest more in firm-general training, the nearer the time when they would need such training to obtain a job in another firm. I have shown, though, that workers do not have good information about the approaching displacement. The results for the entire sample can be rationalized by noting that workers who face liquidity constraints must trade off investment in general training for investment in firm-specific training. Since they do not change the pattern of investment in specific training, they are unable to change that in general training. Undoubtedly other explanations can be offered, but this one is at least consistent with utility-maximizing behavior, the inferences I have made about investment in firm-specific 
training, and the evidence for the entire sample. This view also explains the differences in the changing wage-experlence profiles between laid-off and displaced workers: The former exhibit a steepening wage-experience profile along with a flattening wage-tenure profile, while the opposite pattern exists for workers who face plant closings.

\section{Estimating the Loss}

The value of lost firm-specific investment can be estimated using the results from Section VI along with assumptions about quit behavior. I calculate only the social cost attributable to the worker: The total cost to society of the lost specific human capital--the sum of the worker's and the firm's losses--cannot be calculated without extraneous information on changes in s* as the date of displacement approaches. Whether these are losses that should be compensated is not at issue here; all 1 am measuring is the size of the range of negative returns on firm-specific investment.

The present value of the loss for the typical worker with TN years of tenure in the firm is:

$$
L=H\left[w^{*}(T N)-w(0)\right] \sum_{t=0}^{68-A} \frac{P(T N+t)}{[(1+r)(1+\delta)]} \text {, }
$$

where $L$ is the loss; $P$ is the probability the worker would otherwise have been employed in the firm $t$ years after displacement; $A$ is the worker's age; $H$ is hours worked per year; $w^{*}(T N)$ is the wage rate gross of the cost of investment in specific training for a worker with TN years of tenure, and w(0) is the wage rate the same person would get with tenure of zero years; $r$ is the discount rate, and $\delta$ is the rate of depreciation of firm-specific investment. Throughout $I$ assume $H=2000$; $L$ is calculated over the range of values of $r$ and $\delta$ on the intervals $[0, .10]$ and $[.05, .15]$ respectively, ${ }^{23}$ 
Table 6

Wage Rates by Experience and Time

Remaining unt1l Displacement

\begin{tabular}{lcccccc}
\hline & \multicolumn{5}{c}{} \\
Years before \\
\cline { 2 - 6 } Displacement
\end{tabular}

All Workers

$\begin{array}{rrrrrr}1 & \$ 5.36 & \$ 5.58 & \$ 5.73 & \$ 5.81 & \$ 5.82 \\ 2 & 5.33 & 5.76 & 6.10 & 6.34 & 6.47 \\ 3 & 5.40 & 5.71 & 5.91 & 5.98 & 5.91 \\ 4 & 5.65 & 5.95 & 6.14 & 6.20 & 6.13\end{array}$

Displaced

$\begin{array}{llllll}1 & 5.63 & 5.88 & 6.04 & 6.11 & 6.08 \\ 2 & 5.43 & 5.97 & 6.42 & 6.73 & 6.89 \\ 3 & 5.83 & 6.11 & 6.27 & 6.30 & 6.19 \\ 4 & 6.29 & 6.70 & 6.96 & 7.07 & 7.01 \\ & & & & & \\ & & & \text { Lald-0ff } & & \\ 1 & 5.24 & 5.41 & 5.54 & 5.62 & 5.66 \\ 2 & 5.35 & 5.60 & 5.83 & 6.00 & 6.13 \\ 3 & 5.34 & 5.58 & 5.73 & 5.77 & 5.71 \\ 4 & 5.57 & 5.86 & 5.99 & 5.97 & 5.79\end{array}$

Nonunion

\begin{tabular}{lccccc}
1 & 5.03 & 5.19 & 5.29 & 5.33 & 5.32 \\
2 & 5.09 & 5.41 & 5.67 & 5.84 & 5.92 \\
3 & 4.99 & 5.29 & 5.49 & 5.56 & 5.50 \\
4 & 5.08 & 5.31 & 5.45 & 5.48 & 5.42 \\
& & & Union & & \\
& & & & & \\
1 & 6.30 & 6.66 & 7.00 & 7.30 & 7.55 \\
2 & 5.86 & 6.48 & 7.07 & 7.59 & 8.04 \\
3 & 5.90 & 6.27 & 6.52 & 6.64 & 6.62 \\
4 & 6.74 & 7.42 & 7.83 & 7.92 & 7.68 \\
\hline
\end{tabular}


The wage loss is estimated using the quadratic wage-tenure profile for T-1 that is presented in Table 3. The effect of tenure on the worker's net wage is calculated using the coefficients on $\mathrm{TN}$ and $\mathrm{TN}^{2}$ from that regression. The gross wage loss, however, is the appropriate measure to use in estimating the value of lost firm-specific investment, since it measures the current return on the stock of past firm-specific investment without subtracting any current investment. It is calculated using the coefficients from this same regression under the assumptions that the rates of return to education and firm-specific training are equal, and that the ratio of investment in firm-specific training declines linearly with years of tenure (Mincer, 1974).

I assume that workers would have remained in the firm unless they quit voluntarily. Thus $P$ is calculated as:

$$
P(T N+t)=\prod_{k=0}^{t}\left[1-q_{T N}(k)\right] .
$$

where ${ }^{9}{ }_{T N}$ is the voluntary quit rate of a worker with TN years of tenure. since q cannot be calculated for the workers on whom the estimates in Section UI are based, I use estimates of quit rates as functions of workers' characteristics based on micro data sets with broad coverage. Three of the available studies--Freeman (1980); Mincer-Jovanovic (1981), and Viscusi (1980)--are based on the Panel Study of Income Dynamics. ${ }^{24}$ The other, Mitchel) (1982), uses the Quality of Employment Surveys for 1973 and 1977.

The loss in (8) is calculated for each of the 362 displaced workers included in the sample over whom equation (7) was estimated for the year before displacement. The average loss in the sample is presented in Table 7 for each of the four quit functions and for various pairs of $r$ and $\delta$. The estimated losses (in 1980 dollars) are quite large, even when high values of the discount and depreciation rates are assumed. The failure of workers who 
are later displaced to adjust the path of investment in firm-specific training generates large losses for them when the displacement occurs. ${ }^{25}$ One should remember that I have excluded the firm's share of lost specific training, and have not included the value of lost occupation- or industry-specific training, or the value of time unemployed. Viewed this way the social cost of worker displacement seems quite large compared to the measures of workers' losses that have been produced in the literature.

\section{Conclusions}

In this study I have shown how changes in the horizon for a shared investment like that in firm-specific training affect the amount and burden of that investment. I have used the predictions of that demonstration to analyze how the wage-tenure profile changes in a particular sample of workers as they approach the date of their displacement. The estimates indicate that involuntarily separated workers incur a loss in the form of an unexpected depreciation of the firm-specific human capital in which they have invested. This loss is one component of the social cost of labor-market adjustment. Other components--including the value of the time displaced workers spend unemployed, and the value of lost occupation- and industry-specific training--must be added to obtain an estimate of the total cost of labor-market adjustment. 
Table 7. Average Present Value of Lost Spectfic Training
(In thousands)

$$
\begin{gathered}
(r, \delta) \\
(0, .05) \quad(0, .10) \quad(.05, .10) \quad(.10,10) \quad(.10, .15)
\end{gathered}
$$

\begin{tabular}{|c|c|c|c|c|c|}
\hline $\begin{array}{l}\text { Freeman }(1980) \\
\text { PSID 1968-74, } \\
\text { logtt, al1 workers }\end{array}$ & $\$ 11.5$ & $\$ 8.3$ & $\$ 6.5$ & $\$ 5.4$ & $\$ 4.7$ \\
\hline $\begin{array}{l}\text { Mincer-Jovanovic (1981) } \\
\text { PSID 1975-76, } \\
\text { OLS, men }\end{array}$ & 10.6 & 7.9 & 6.2 & 5.2 & 4.6 \\
\hline $\begin{array}{l}\text { Mitchel1 }(1982) \\
\text { QES 1973, 1977, } \\
\text { prob1t, men and } \\
\text { women separately }\end{array}$ & 15.7 & 10.5 & 7.8 & 6.2 & 5.3 \\
\hline $\begin{array}{l}\text { Viscust }(1980) \\
\text { PSID 1975-76, } \\
\text { logit, men and women } \\
\text { separately }\end{array}$ & 12.1 & 8.8 & 6.8 & 5.7 & 4.9 \\
\hline
\end{tabular}

Quit Function 


\section{REFERENCES}

John Abowd and Drley Ashenfelter, "Anticipated Unemployment, Temporary Layoffs, and Compensating Wage Differentials," in Sherwin Rosen, ed. Studies in Lahor Mackets. Chicago: University of Chicago Press, 1981.

Joseph Altonji and Robert Shakotko, "Do Wages Rise with Job Seniority?" Unpublished Paper, Columbia University, July 1984.

Robert Baldwin, "Rent-Seeking and Trade Policy: An Industry Approach." Unpublished Paper, University of Wisconsin, 1984.

Malcolm Bale, "Estimates of Trade-Displacement Costs for U.S. Workers," Ioucoal of International Economies, 6 (1976): 245-250.

Ann Bartel and George Borjas, "Wage Growth and Job Turnover: An Empirical Analysis," in Sherwin Rosen, ed. Studies in Labor Mackets. Chicago: University of Chicago Press, 1981.

Henry Farber, "The Determination of the Status of Union Workers," Econometcica, 51 (1983): 1417-1437.

Richard Freeman, "The Exit-Voice Trade off in the Labor Market," Quacterly Journal of Economics, $94(1980): 643-674$.

Graham Glenday and Glenn Jenkins, "Industrial Dislocation and the Private Cost of Labor Adjustment," Contemporary Rolicy Issues (January 1984): 23-36.

Masanori Hashimoto, "Wage Reduction, Unemployment and Specific Human Capital," Eranomic Inquicz, 13 (1975): 485-503.

Louis Jacobson, "Earnings Losses of Workers Displaced from Manutacturing Industries," in William Dewald, ed. Ihe Impact of International Irade and Inyestment on Emploxment. Washington: GPO 1978.

Glenn Jenkins and Claude Montmarquette, "Estimating the Private and Social Opportunity Cost of Displaced Workers," Review of Eronomies and Statistics, 61 (1979): 342-353.

George Johnson and Kenwood Youmans, "Union Relative Wage Effects by Age and Education," Industrial and Laboc Relations Beview, 24 (1971): 171-179.

Thomas Johnson, "Returns from Investment in Human Capital," Amecican Economic Reuiew, 60 (1970): 546-560.

Edward Lazear, ugency, Earnings Profiles, Productivity and Hours Restrictions," American Econonic Reyiew, 71 (1981): 606-620. 

Jac ob Mincer, Schooling, Expecience and Earninos. New York: National Bureau of
Ec onomic Research, 1974.

Jacob Mincer and Boyan Jouanovic, "Labor Mobility and Wages," in Sherwin Rosen, ed. Studies in Lator Mackets. Chicago: University of Chicago Press,
1981.

Olivia Mitchell, "Fringe Benefits and Labor Mobility," Joucoal of Human Resources, 17 (1982): 286-298.

George Neumann, 'The Direct Labor Market Effects of the Trade Adjustment Assistance Program, in William Dewald, ed. Ihe Ionact of International Icade on Emploxment. Washington: GPO, 1978.

Steven Sandell, "Job Search by Unemployed Women: Determinants of the Asking wage," Industrial and Laboc Relations Review, 33 (1980): 368-378.

- Age Discrimination and Labor Market Problems of Displaced Older Male Workers," Unpublished Paper, Pennsyluania State
University, 1983.

Kathryn Shaw, "A Formulation of the Earnings Function Using the Concept of Occupational Investment," Joucnal of Human Resoucces, 19 (1984): 319-340.

Robert Tope1, "Equilibrium Earnings, Turnover, and Unemployment," Jauraal of Labor Economics, 2 (1984): 500-522.

W. Kip Viscusi, "Sex Differences in Worker Quitting," Review of Eronomics and Statistics, $62(1980)$ : 388-398.

Michael Wachter, "The Training Component of Growth Policies," Unpublished Paper, University of Pennsyluania, 1983. Richard Wilcock and Walter Franke, Unwabted Wockecs. Glencoe, IL: Free Press,
1963. 


\section{FOOTNOTES}

1. One example of this kind of response is the introduction of bills requiring prior notification of a plant closing. The. National Employment Priorities Act," 98:1, H.R. 2847, mandates at least one year's prior notification of a permanent layoff or a plant closing involving more than 100 workers. Such legisiation is similar to what exists in many other developed countries.

2. See Congressional Budget Office, Dislocated Workers: Issues and Eedecal Options, July 1982, Chapter 3, for discussion of various approactes to defining the issue.

3. In the 1960 s this difficulty coupled with politics to prevent any payments to workers under the Trade Adjustment Assistance Act of 1962. Beginning in 1969 payments were made increasingly to workers whose employer's product market merely contained foreign competitors.

4. Congressional Budget Office, op. cit., uses the Current Population Survey to classify unemployed workers, but does not base its criteria for displacement on the reason for job loss. Sandell-Shapiro (1983) estimate the economic and demographic characteristics of job losers, not classified by reason for loss, in a sample of older workers only.

5. Currently employed workers were considered to be laid-off or displaced if they changed employers for one of these reasons within the past year. Unemployed or retired individuals were counted as laid-off or displaced in the most recent year in which they reported the involuntary separation.

6. All the information is calculated using the survey's sampling weights (so that the characteristics are comparable to national averages).

7. This finding contrasts with the evidence in Wilcock and Franke (1963, $p$. 40) showing a median age above 45 among workers displaced in the closings of a group of meat-packing plants.

8. That the previous wage, not merely the components of the vector $x$, affects the reservation wage is suggested by the results of Kiefer-Neumann (1979) and Sande II (1980).

9. I assume, following Farber (1983), that such jobs must be rationed.

10. Obuiously, some firms and workers whose relationship lasts longer than they expected will experience unexpectedly high returns on their joint investment. For that reason these estimates may be viewed as tests for the existence of, and measures of ine size of, the lower tail of the distribution of returns to firm-specific investment. Since many social policies focus on compensating people in the lower tails of various distributions, e.g., income, weeks employed, this approach is consistent with the analysis of other policies.

11. That there are such skills is suggested by Shaw (1984). In addition to the 
labor-market costs that are ignored, there are other costs, such as unexpected capital losses on immobile housing stocks, that must be included in a complete accounting of the social costs of adjustment to industrial change.

12. All that is required for the results to go through is that $\theta^{\prime}<C^{n}$.

13. This too is a simplifying assumption designed to ease the exposition; the results do not depend on it.

14. Obviously, if the $z$ differ the split will not be centered on .5; but the qualitative results will remain unchanged.

15. See, for example, Mincer-Jovanovic, 1981, for an example linking these profiles to patterns of firm-specific investment. While the argument here and in most of the literature has based the wage-tenure profile on investment in firm-specific training, one might inquire whether a similar link could be established in a model of bonding such as Lazear's (1981). If both parties' horizons suddenly shorten in such a model, new workers will be less willing to forego current wages in exchange for higher wages later. Indeed, with a sufficiently short horizon workers will not sacrifice any current wages, and the profile will be flat. Thus the bonding model seems observationally equivalent to the model developed here; in both a flattening of the wage-tenure profile implies workers have acquired substantial information. (However, the models may have substantially different implications for appropriate policies on compensation.)

16. Hashimoto (1975) was the first to recognize the importance of the specific-general distinction in discussing worker displacement. However, he ignored the game-theoretic aspects of specific investment and the effect of changing horizons, and provided no link between empirical results and the theory of specific investment. Bartel-Borjas (1981) were also aware of the role of specific training in separations, but they did not focus on the wage-tenure profile's relation to time remaining on the job as we do below.

17. While tenure in a particular job is avallable more often in this panel, that measure does not reflect firm-specific investment very well. Consider two workers, one with the firm for five years on five separate jobs, each lasting a year, the other in the firm for one year on the same job. Though each has tenure of one year on the job, the appropriateness of using total tenure is apparent.

18. Yet another problem limiting the sample size is the restriction of the data to household heads. Since some small fraction (below 10 percent) of the households change heads each year, and since the data of interest are reported for household heads, observations must be discarded because the information on tenure and other variables cannot be linked to the date of displacement.

19. As people separated involuntarily in 1977-81 are included in the sample, wage rates are made comparable across calendar time for $T-i, i=1, \ldots, 4$, by inflating using the growth in private nonfarm hourly earnings between the time the worker's wage is observed and 1980 .

20. One possibility that might explain the apparent lack of flattening is that the linear, and even the quadratic forms of TN misspecify the equation, and that newer workers must be treated separately. To examine this I reestimated 
(7) for each of the four samples, first including a dumy variable for workers with at most 1 year of tenure, then including a dumy variable for those with at most 2 years of tenure. Only one of these ight variables added significantly to the equations' explanatory power, and in no case did their addition change the inference that there is little flattening of the profile as displacement approaches.

21. Equations (7) were also estimated separately for years T-1,.T-4 for the samples disaggregated by union status, and disaggregated by reason for involuntary separation. Only for T-4 was the hypothesis that the layoff-displaced subsamples could be pooled rejected at the 5-percent level of confidence, and only for $T-1$ for the union-nonunion disaggregation was the hypothesis rejected even at the 10-percent level.

22. This conclusion corroborates the sense of surprise expressed by workers and their representatives when plants close. One local union president discussed how his employer expanded for several years and then, "... we were notified that in three weeks we would be shut down. The people in the town were quite shocked.... It completely caught us off guard." (James Savoy, "Statement," House Subcommittee on Labor-Management Relations, 98:2, Heacings, May 4, 1984.

23. This range brackets the estimates of the rate of depreciation of on-the-job training in Johnson (1970).

24. Because Mincer-Jovanovic use OLS estimation, the simulated quit rate becomes negative for high values of tenure in the firm. I arbitrarily restrict $q$ to be nonnegative in the simulations.

25. Since these estimates exclude lost fringe benefits, particularly unvested pension benefits, even they underestimate the lost future remuneration. 
Table A.1

Eatimates of Other Coefficlents in the Regression in Table 2 a/

\begin{tabular}{|c|c|c|c|c|}
\hline Varlable & 1 & $\begin{array}{c}\text { Years Befo } \\
2\end{array}$ & $\begin{array}{l}\text { placement } \\
3\end{array}$ & 4 \\
\hline Education & $\begin{array}{l}.0358 \\
(4.75)\end{array}$ & $\begin{array}{l}.0400 \\
(4.80)\end{array}$ & $--b$ & -_b \\
\hline Union Member & $\begin{array}{r}.288 \\
(6.01)\end{array}$ & $\begin{array}{r}.230 \\
(4.43)\end{array}$ & $\begin{array}{r}.176 \\
(3.36)\end{array}$ & $\begin{array}{r}.313 \\
(5.62)\end{array}$ \\
\hline White & $\begin{array}{r}.128 \\
(2.98)\end{array}$ & $\begin{array}{r}.047 \\
(.90)\end{array}$ & $\begin{array}{r}.092 \\
(1.71)\end{array}$ & $\begin{array}{r}.171 \\
(3.34)\end{array}$ \\
\hline Married & $\begin{array}{l}.050 \\
(.92)\end{array}$ & $\begin{array}{l}.052 \\
(.77)\end{array}$ & $\begin{array}{r}.095 \\
(1.37)\end{array}$ & $\begin{array}{r}-.073 \\
(-1.04)\end{array}$ \\
\hline Male & $\begin{array}{r}.317 \\
(4.77)\end{array}$ & $\begin{array}{r}.303 \\
(3.80)\end{array}$ & $(3.66)$ & $\begin{array}{r}.454 \\
(5.75)\end{array}$ \\
\hline South & $\begin{array}{r}-.182 \\
(-4.36)\end{array}$ & $\begin{array}{r}-.139 \\
(-2.79)\end{array}$ & $\begin{array}{r}-.035 \\
(-.63)\end{array}$ & $\begin{array}{l}.025 \\
(.45)\end{array}$ \\
\hline $\begin{array}{l}\text { SMSA w1th c1ty } \\
>500,000\end{array}$ & $\begin{array}{l}.026 \\
(.60)\end{array}$ & $\begin{array}{r}.099 \\
(2.05)\end{array}$ & $\begin{array}{r}.097 \\
(1.80)\end{array}$ & $\begin{array}{r}.128 \\
(2.39)\end{array}$ \\
\hline \multicolumn{5}{|l|}{ Industry: } \\
\hline Manufacturing & $\begin{array}{l}-.126 \\
(-2.48)\end{array}$ & $\begin{array}{r}-.064 \\
(-1.23)\end{array}$ & $\begin{array}{r}-.028 \\
(-.51)\end{array}$ & $\begin{array}{r}-.082 \\
(-1.47)\end{array}$ \\
\hline Trade & $\begin{array}{r}-.269 \\
(-4.73)\end{array}$ & $\begin{array}{r}-.127 \\
(-2.11)\end{array}$ & $\begin{array}{l}.018 \\
(.27)\end{array}$ & $\begin{array}{r}-.068 \\
(-1.00)\end{array}$ \\
\hline Finance and Servicea & $\begin{array}{r}-.172 \\
(-2.97)\end{array}$ & $\begin{array}{r}-.116 \\
(-1.78)\end{array}$ & $\begin{array}{r}-.041 \\
(-.57)\end{array}$ & $\begin{array}{r}-.073 \\
(-1.05)\end{array}$ \\
\hline \multicolumn{5}{|l|}{ Occupat1on: } \\
\hline Professionals and Managers & $\begin{array}{r}.332 \\
(5.08)\end{array}$ & $(7.02)$ & $\begin{array}{r}.471 \\
(5.20)\end{array}$ & $\begin{array}{r}.466 \\
(4.71)\end{array}$ \\
\hline Craft Workers & $\begin{array}{r}.182 \\
(2.81)\end{array}$ & $\begin{array}{r}.308 \\
(4.16)\end{array}$ & $\begin{array}{r}.304 \\
(3.91)\end{array}$ & $\begin{array}{r}.234 \\
(2.91)\end{array}$ \\
\hline Operatives and Laborers & $\begin{array}{l}.044 \\
(.72)\end{array}$ & $\begin{array}{r}.144 \\
(2.30)\end{array}$ & $\begin{array}{l}.043 \\
(.64)\end{array}$ & $\begin{array}{r}.071 \\
(1.06)\end{array}$ \\
\hline
\end{tabular}

at-statistics in parentheses.

$b_{A}$ vector of three dummy variables indicating schooling attalnment was included. 